\title{
A fuzzy hybrid approach for project manager selection
}

\author{
Ahmad Jafarnejad Chaghooshi ${ }^{a}$, Alireza Arab ${ }^{b^{*}}$ and Seyyed Jalaladdin Hosseini Dehshiri ${ }^{b}$
}

${ }^{a}$ Professor, Faculty of management, University of Tehran, Tehran, Iran

${ }^{b}$ M.S. student of Industrial Management, Faculty of management, University of Tehran, Tehran, Iran

\section{H R O N I C L E}

Article history:

Received October 25, 2015

Received in revised format:

December 12, 2015

Accepted January 2, 2016

Available online

January 42016

Keywords:

Project manager

Multi Criteria Decision Making

FDEMATEL

FVIKOR

\section{A B S T R A C T}

\begin{abstract}
Suitable project manager has a significant impact on successful accomplishment of the project. Managers should possess such skills in order to effectively cope with the competition. In this respect, selecting managers based on their skills can lead to a competitive advantage towards the achievement of organizational goals. selection of the suitable project manager can be viewed as a multi-criteria decision making (MCDM) problem and an extensive evaluation of criteria, such as Technical skills, experience skills, Personal qualities and the related criteria must be considered in the selection process of project manager. The fuzzy set theory and MCDM methods appears as an essential tools to provide a decision framework that incorporates imprecise judgments and multi criteria nature of project manager selection process inherent in this process. This paper proposes the joint use of the Fuzzy DEMATEL (FDEMATEL) and Fuzzy VIKOR methods for the decision-making process of selecting the most suitable managers for projects. First, with the opinions of the senior managers based on project management competency model (ICB-IPMA), all the criteria required for the selection are gathered. Then the FDEMATEL method is used to prioritize the importance of various criteria and FVIKOR used to rank the alternatives in a preferred order to select the best project managers from a number of alternatives. Next, a real case study used to illustrate the process of the proposed method. Finally, some conclusions are discussed at the end of this study.
\end{abstract}

(C) 2016 Growing Science Ltd. All rights reserved.

\section{Introduction}

Project is a temporary endeavor undertaken to create a unique product, service or result (Archibald \& Archibald, 2013, p. 3). Nowadays, with the increasing complexity of organizations, requiring more complex and extended projects to meet their needs. Project managers are responsible for the leadership role in projects (Müller \& Turner, 2010). The selection of well-trained managers ready for the leadership of the projects is a critical success factor for organizations. On the other hand employing a poorly prepared project manager, without the necessary skill, knowledge and experience, is something that could threat the success of the project (Pinto \& Slevin, 1987; Möller \& Turner, 2007). Successful project managers should have relevant experience and knowledge of the technology required by the

* Corresponding author. Tel: +98 9112599003

E-mail address: alireza.arab@ut.ac.ir (A. Arab)

C 2016 Growing Science Ltd. All rights reserved. doi: $10.5267 /$ j.dsl.2016.1.001 
project they manage (Zavadskas et al., 2012; Vainiunas et al., 2010). There are some traditional methods used in the project manager selection process such as, completion of application forms, interview and background investigation. These traditional techniques generally come to a conclusion on the basis of the subjective judgment of decision makers, which makes the accuracy of the results questionable (Zhang \& Liu, 2011; Robertson \& Smith, 2001; Petrovic-Lazerevic, 2001). Thus, In order to find the suitable project manager, developing effective selection methods is vital (Dagdeviren, 2010). Selection of the suitable project manager can be viewed as a multi-criteria decision making (MCDM) problem and an extensive evaluation of criteria, such as Technical skills, experience skills, Personal qualities and the related criteria must be considered in the selection process of project manager. As in many decision problems, project manager selection problem is extremely complex in real life; humans generally fail to make a good prediction for quantitative problems, in contrast they may make accurate guesses in qualitative forecasting. Because of the imprecise expressions, a fuzzy approach is commonly used in decision problems. Fuzzy sets theory appears as an important tool to provide a decision framework that incorporates imprecise judgments inherent in the project manager selection process and permit the translation of linguistic expressions into numerical ones. (Dursun \& Karsak, 2010). This paper proposes fuzzy integrated multi-stages evaluation model towards enhancing the execution procedures of Project manager selection processes. The proposed methodology consists of fuzzy DEMATEL and fuzzy VIKOR methods under multiple criteria. First, with the opinions of the senior managers based on project manager's competency model (IPMA, 2006), all the criteria required for the selection are gathered. Then The FDEMATEL method is used to prioritize the importance of various criteria and FVIKOR used to rank the alternatives in a preferred order to select the best project managers from a number of alternatives. A real case study in Zarrin Balan Shomal Company is used to illustrate the process and potential benefits of the proposed framework. The rest of the paper is organized as follows: In the next section, comments on the recent literature are summarized as concerns project manager selection problem. A hybrid FMCDM model combining FDEMATEL and FVIKOR for assessment of project managers is developed in Section 3. In Section 4, an empirical case conduced in Zarrinbalan company, is presented to demonstrate the proposed method. Finally, conclusions and future research directions are provided in Section 5.

\section{Literature Review}

Multi criteria decision making (MCDM) has been used in selecting project manager. For example, Chen and Cheng (2005) developed a fuzzy MCDM method for information system project manager selection. Xing and A-di (2006) analyzed the significance of choosing an eligible project manager in their study. They tried to quantitatively assess the ability and quality of a project manager by implementing fuzzy analytical hierarchy process which was based on triangular fuzzy numbers. Hui et al. (2008) tried to demonstrate a suitable competency based framework. Zavadskas et al. (2008) developed a multi criteria methodology for project manager selection based on grey criteria. Liqin et al. (2009) adopted a fuzzy comprehensive evaluation methods in the selection of a project manager. Rashidi et al. (2010) combined fuzzy systems, ANNs and Genetic algorithm for choosing a qualified project manager. Insight into the relevant literatures to project manager's selection reveals that majority of the reviewed studies do not use combination of FDEMATEL and FVIKOR for project managers selection problem, which this is the novelty of this research.

The important step in project manager selection problem is to identify the selection criteria. Researchers have their own opinion on the project managers' selection criteria (El-Sabaa, 2001). Technical skills, conceptual skills and human skills are considered by Godwin (1983), as the main four skills project managers cannot do without. Analysis and design, Programming, Interpersonal skills, business knowledge, IS environment knowledge, IS applications knowledge are considered by Chen and Cheng (2005) as the main four skills project managers. Shih et al. (2007) considered Knowledge tests (language test, professional test, safety rule test), skill tests (professional skills, computer skills) and interviews as the main criteria for On-line manager Recruitment in a local chemical company. 
Table 1

Criteria used for different applications

\begin{tabular}{|c|c|c|c|}
\hline Proposed by & Techniques & $\begin{array}{l}\text { Empirical } \\
\text { application }\end{array}$ & Main criteria \\
\hline Al-Harbi (2001) & AHP & $\begin{array}{l}\text { Choose the best } \\
\text { contractors of the project }\end{array}$ & $\begin{array}{l}\text { Experience, Financial stability, Quality performance, Manpower resources, } \\
\text { Equipment resources }\end{array}$ \\
\hline $\begin{array}{l}\text { Dainty et al. } \\
\quad(2005)\end{array}$ & statistical technique & $\begin{array}{l}\text { Construction managers } \\
\text { selection }\end{array}$ & $\begin{array}{l}\text { Achievement orientation, Initiative, Information seeking, Focus on client's } \\
\text { needs, Impact and influence, Directiveness, Teamwork and cooperation, Team } \\
\text { leadership, Analytical thinking, Conceptual thinking, Self-control, Flexibility }\end{array}$ \\
\hline $\begin{array}{l}\text { Xing \& Zhang } \\
\quad(2006)\end{array}$ & FAHP & project manager selection & Project manager's abilities: Knowvledge, Capability, Character, Body \\
\hline Chen \& Lee (2007) & ANP & $\begin{array}{l}\text { Performance evaluation } \\
\text { model for project } \\
\text { managers }\end{array}$ & Technical competence, performance influence factor and behaviors factor. \\
\hline $\begin{array}{l}\text { Zavadskas et al. } \\
\qquad(2008)\end{array}$ & $\begin{array}{l}\text { COPRAS, grey } \\
\text { relations }\end{array}$ & project manager selection & $\begin{array}{l}\text { Education level, Age, Racial stock, Dependability, Experience (in similar } \\
\text { projects), Self-views, Self-relevant goals, Paperwork, Job stress, Pay, Problem } \\
\text { specification, Conceptual and organizational skills, Project management skills, } \\
\text { Business skills (markets), Technical skills, Appropriate computer, Control }\end{array}$ \\
\hline $\begin{array}{l}\text { Bayraktaroglu et } \\
\text { al. (2009) }\end{array}$ & ANP & $\begin{array}{l}\text { comparison of the project } \\
\text { managers }\end{array}$ & $\begin{array}{l}\text { Usability Factors (Navigation, Interaction, Learnability, Ease of Use, Response } \\
\text { Time, Memorability, Efficiency, Satisfaction) } \\
\text { Functionality Factors (Security, Search Options, Information Provision, } \\
\text { Services/Facilities, User Guidance or Support, Customizability, Autorun) }\end{array}$ \\
\hline Liqin et al. (2009) & $\begin{array}{l}\text { fuzzy comprehensive } \\
\text { evaluation }\end{array}$ & project manager selection & $\begin{array}{l}\text { Site management capacity, Technical level, Level of leadership, Personal } \\
\text { qualities }\end{array}$ \\
\hline $\begin{array}{l}\text { Vainiūnas et al. } \\
\qquad(2010)\end{array}$ & AHP, TOPSIS & $\begin{array}{l}\text { presents ranking } \\
\text { technique of design } \\
\text { projects' managers }\end{array}$ & Technical skills, experience skills \\
\hline $\begin{array}{l}\text { Torfi \& Rashidi } \\
\text { (2011) }\end{array}$ & FTOPSIS, AHP & project manager selection & $\begin{array}{l}\text { Technical and professional records, Educational Background, Demographic } \\
\text { features, General Management abilities }\end{array}$ \\
\hline $\begin{array}{l}\text { Kelemenis et al. } \\
\text { (2011) }\end{array}$ & FTOPSIS & Managers selection & $\begin{array}{l}\text { creativity/innovation, problem solving/decision making, conflict } \\
\text { management/negotiation, empowerment/delegation, strategic planning, specific } \\
\text { presentation skills, communication skill, team management, diversity } \\
\text { management, self-management, professional experience, educational } \\
\text { Background }\end{array}$ \\
\hline $\begin{array}{l}\text { Chen \& Hung } \\
\text { (2012) }\end{array}$ & FTOPSIS & project leaders selection & $\begin{array}{l}\text { Research experiment, Profession skill ability, English ability, Work attribute, } \\
\text { Emotion control ability }\end{array}$ \\
\hline $\begin{array}{l}\text { Afshari \& Yusuff } \\
\qquad(2012)\end{array}$ & Delphi & project manager selection & $\begin{array}{l}\text { Education, Planning and control, Communication, Experience, Leadership, } \\
\text { Negotiation skills, General management, Team development, Resource } \\
\text { management, } \\
\text { Time management, Human skills, Technical skills, Computer, Problem solving, } \\
\text { Quality Management }\end{array}$ \\
\hline $\begin{array}{l}\text { Afshari et al. } \\
\text { (2012) }\end{array}$ & FSAW & project manager selection & $\begin{array}{l}\text { Basic Requirements, Project Management Skills, Management Skills, } \\
\text { Interpersonal Skills }\end{array}$ \\
\hline $\begin{array}{l}\text { Zavadskas et al. } \\
\text { (2012) }\end{array}$ & AHP, ARAS & $\begin{array}{l}\text { Assessment of projects } \\
\text { managers in construction }\end{array}$ & $\begin{array}{l}\text { Education, Criteria group of experience of applicant, Criteria group of personal } \\
\text { skills of applicant }\end{array}$ \\
\hline $\begin{array}{l}\text { Jazebi \& Rashidi } \\
\text { (2013) }\end{array}$ & fuzzy system & project manager selection & $\begin{array}{l}\text { Technical and professional } \\
\text { Background, Educational background, Demographic Features, General } \\
\text { management abilities }\end{array}$ \\
\hline $\begin{array}{l}\text { Varajão \& Cruz- } \\
\text { Cunha (2013) }\end{array}$ & AHP & project manager selection & $\begin{array}{l}\text { Knowledge (Technical competences, Behavioral competences, Contextual } \\
\text { competences), Experience(Technical competences, Behavioural competences, } \\
\text { Contextual competences) }\end{array}$ \\
\hline Hadad et al. (2013) & $\begin{array}{l}\text { Mann-Whitney- } \\
\text { Wilcoxon U test }\end{array}$ & project manager selection & $\begin{array}{l}\text { Criteria regarding the project's allocated budget and actual Costs, project's } \\
\text { resources and their consumption, the project's time span, project's risks }\end{array}$ \\
\hline Chen et al. (2013) & FTOPSIS & Project Leader Selection & $\begin{array}{l}\text { General ability: English proficiency, communication ability, work attributes and } \\
\text { emotional steadiness } \\
\text { professional ability: French language ability, product knowledge, market } \\
\text { knowledge, } \\
\text { accounting knowledge, law knowledge and } \\
\text { Mechanical knowledge }\end{array}$ \\
\hline $\begin{array}{l}\text { Manaan et al, } \\
\quad(2014)\end{array}$ & Fuzzy Competency & project manager selection & $\begin{array}{l}\text { Knowledge of appropriate site layout techniques for repetitive construction } \\
\text { works, Dedication in helping works contractors achieve works schedule, } \\
\text { Knowledge of appropriate technology transfer for repetitive construction works, } \\
\text { Effective time management practices on all project sites, Ability to provide } \\
\text { effective solutions to conflicts while maintaining good relationships, Ease with } \\
\text { which works contractors are able to approach the PM with their problem, } \\
\text { Volunteering to help works contractors to solve personal problems }\end{array}$ \\
\hline $\begin{array}{l}\text { Dodangeh et al. } \\
\quad(2014)\end{array}$ & FMCDM & project manager selection & $\begin{array}{l}\text { Basic requirements, Project management skills, Management skills, } \\
\text { Interpersonal skills }\end{array}$ \\
\hline $\begin{array}{l}\text { Sadeghi et al. } \\
\text { (2014) }\end{array}$ & $\begin{array}{l}\text { FTOPSIS, Goal } \\
\text { programming }\end{array}$ & project manager selection & $\begin{array}{l}\text { The Knowledge Competencies for Project Managers, The Performance } \\
\text { Competencies for Project Managers, The Behavioral Competencies for Project } \\
\text { Managers }\end{array}$ \\
\hline This paper & $\begin{array}{l}\text { FDEMATEL, } \\
\text { FVIKOR }\end{array}$ & project manager selection & $\begin{array}{l}\text { Site management capacity(Project management, Cost management, Quality } \\
\text { management, Purchase and machinery and equipment management), Technical } \\
\text { level(Level of expertise linked to a specific project, General technical level in } \\
\text { construction), Level of leadership(Communication skills, Human resource } \\
\text { management capacity, Risk management capability, Ability to create efficient } \\
\text { working environment), Personal qualities(Achievement-oriented and good at } \\
\text { action, Ability to influence, Cognitive ability), Contextual competences(Project } \\
\text { orientation, Program orientation, Portfolio orientation, Project program and } \\
\text { portfolio implementation, Permanent organization, Health, security, safety and } \\
\text { environment) }\end{array}$ \\
\hline
\end{tabular}


Baykasoglu et al. (2007) considered Communication skills, technical expertise, problem solving ability, decision making skills, available time period, salary request as the required skills for Project team member's selection. Insight into the relevant literatures to project manager selection reveals that majority of the reviewed studies do not provide a systematic method for criteria selection (Chen \& Hung, 2012; Kelemenis et al., 2011; Chen \& Lee, 2007; Afshari et al., 2012; Sadeghi et al., 2014; Xing \& A-di, 2006; Torfi \& Rashidi, 2011; Al-Harbi, 2001). Proper criteria selection is the building block for successful project manager selection. Hence this paper aims to provide a systematic method for criteria selection based on expert's idea and project manager's competency model. Table 1 shows extensive literature Review of papers relate to project manager selection problem.

\section{A hybrid FMCDM model for evaluating project managers}

In this section, a hybrid MCDM model based on FDEMATEL technique and fuzzy VIKOR method is presented to address the problem of project manager selection with interdependence among criteria. In short, the proposed model for evaluation of project managers consists of two main stages: (1) constructing the influential relation map (IRM) among the dimensions and criteria and calculating their influential weights by FDEMATEL technique, and (2) ranking project managers through the fuzzy VIKOR method. The flowchart of the proposed hybrid MCDM model is shown in Fig. 1.

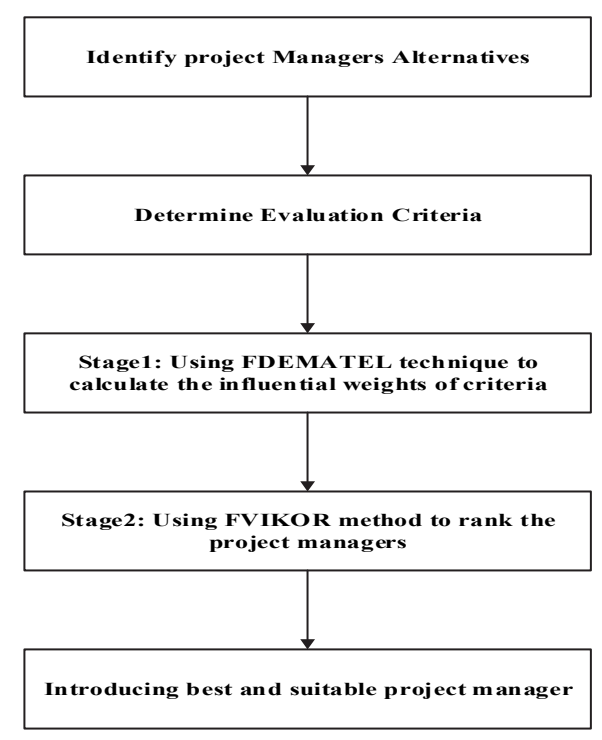

Fig. 1. Flowchart of the proposed hybrid MCDM model

\subsection{The FDEMATEL Technique}

The DEMATEL technique originated from the Geneva Research Centre of the Battelle Memorial Institute is especially pragmatic to visualize the structure of complicated causal relationships and to clarify the essentials of the problems (Baykasoğlu et al., 2013). It is more suitable in real-life applications and has been widely used in various decision making problems (Dalalah et al., 2011; Cebi, 2013; Liu et al., 2014). The DEMATEL technique can help decision makers understand the interdependence of criteria through matrices or digraphs and restrict the relations that reflect characteristics within an essential systemic and developmental trend. The procedure of the FDEMATEL algorithm can be given as follows:

Step 1. Compute the group direct-influence matrix 
Let $C=\left\{C_{1}, C_{2}, \ldots, C_{n}\right\}$ be a set of criteria, where $C_{j}$ denotes the $j$ th criteria, $\mathrm{j}=1,2, \ldots, \mathrm{n} ; E=$ $\left\{E_{1}, E_{2}, \ldots, E_{K}\right\}$ be a set of experts, where $E_{K}$ represents the $k$ th expert, $\mathrm{K}=1,2, \ldots, \mathrm{K}$. First, experts are asked to indicate the direct effect that factor $C_{i}$ has on criteria $C_{j}$, by applying linguistic variables (Lin $\& \mathrm{Wu}, 2004)$. These linguistic terms are shown in Table 2.

\section{Table 2}

The correspondence of linguistic terms and linguistic values (Lin \& $\mathrm{Wu}, 2004$ )

\begin{tabular}{cc}
\hline Linguistic terms & Linguistic value \\
\hline Very High Influence (VH) & $(0.75,1.0,1.0)$ \\
High Influence (H) & $(0.5,0.75,1.0)$ \\
Low Influence (L) & $(0.25,0.5,0.75)$ \\
Very Low Influence (VL) & $(0,0.25,0.5)$ \\
No Influence (No) & $(0,0,0.25)$ \\
\hline
\end{tabular}

Then, the initial direct-influence matrix $z_{k}=\left[z_{i j}{ }^{k}\right]_{n \times n}$ provided by the $k$ th expert $E_{K}$ can be set up, where $z_{i j}{ }^{k}$ represents the judgment on the existence of the interrelationship between factors $C_{i}$ and $C_{j}$. Next, it must acquire average the assessment of executives' preferences using:

$$
\tilde{z}=\frac{\tilde{x}^{1} \oplus \tilde{x}^{2} \oplus \tilde{x}^{3} \oplus \ldots \oplus x^{p}}{p}
$$

Then, fuzzy matrix $\tilde{z}$ is produced, which is called initial direct relation fuzzy matrix. In this matrix, $\tilde{z}_{i j}=\left(l_{i j}, m_{i j}, u_{i j}\right)$ are triangular fuzzy numbers and $\tilde{z}_{i j}(i=1,2, \ldots, n)$ will be regarded as triangular fuzzy number $(0,0,0)$ whenever is necessary.

Step 2. Calculate the normalized direct-influence matrix by normalizing initial direct-relation fuzzy matrix, we acquire normalized direct-relation fuzzy matrix $\widetilde{H}$ by using:

$$
\widetilde{H}_{i j}=\frac{\tilde{z}_{i j}}{r}=\left(\frac{l_{i j}^{\prime}}{r}, \frac{m_{i j}^{\prime}}{r}, \frac{u_{i j}^{\prime}}{r}\right)=\left(l_{i j}^{\prime \prime}, m_{i j}^{\prime \prime}, u_{i j}^{\prime \prime}\right)
$$

In Which:

$$
r=\max _{1 \leq i \leq n}\left(\sum_{j=1}^{n} u_{i j}\right)
$$

Step 3. Derive the total-influence matrix

Total-relation fuzzy matrix is defined as:

$$
T=\lim _{k \rightarrow+\infty}\left(\widetilde{H}^{1} \oplus \widetilde{H}^{2} \oplus \ldots \oplus \widetilde{H}^{k}\right)
$$

where $\tilde{t}_{i j}=\left(l_{i j}{ }^{t}, m_{i j}{ }^{t}, u_{i j}{ }^{t}\right)$ and:

$$
\begin{aligned}
& {\left[l_{i j}^{\mathrm{t}}\right]=H_{l} \times\left(I-H_{l}\right)^{-1}} \\
& {\left[m_{i j}^{\mathrm{t}}\right]=H_{m} \times\left(I-H_{m}\right)^{-1}} \\
& {\left[u_{i j}^{\mathrm{t}}\right]=H_{u} \times\left(I-H_{u}\right)^{-1}}
\end{aligned}
$$

Step 4. Defuzification of Total-relation fuzzy matrix by using: 
Step 5. Build the influential relation map (IRM)

At this step, the sum of the rows and the sum of the columns within the total-influence matrix $\mathrm{T}$ are respectively expressed as the vectors $\widetilde{D}_{i}$ and $\widetilde{R}_{i}$ using:

$$
\begin{aligned}
& \widetilde{D}=\left(\widetilde{D}_{i}\right)_{n \times 1}=\left[\sum_{j=1}^{n} \widetilde{T}_{i j}\right]_{n \times 1} \\
& \widetilde{R}=\left(\tilde{R}_{i}\right)_{1 \times n}=\left[\sum_{i=1}^{n} \widetilde{T}_{i j}\right]_{1 \times n}
\end{aligned}
$$

Where $D_{i}$ denotes the sum of the $i$ th row in matrix T and shows the sum of the direct and indirect effects that factor $i$ has on the other factors. Similarly, $R_{i}$ denotes the sum of the $j$ th column in matrix $\mathrm{T}$ and shows the sum of direct and indirect effects that factor $\mathrm{j}$ has received from the other factors. Let $i=j$ and ,$j \in\{1,2, \ldots, n\}$; the horizontal axis vector $(\mathrm{D}+\mathrm{R})$ is then defined by adding $\mathrm{r}$ to $\mathrm{c}$, Which illustrates the strength of influences that are given and received of the factor. That is, $(D+R)$ shows the degree of the central role that the factor plays in the system. Similarly, the vertical axis vector (D-R) is created by subtracting $\mathrm{R}$ from $\mathrm{D}$, which shows the net effect that the factor contribute to the system. If $\left(d_{j}-r_{j}\right)$ is positive, then factor $j$ has a net influence on other factors, and if $\left(d_{j}-r_{j}\right)$ is negative, then factor $j$ is being influenced by other factors on the whole. Finally, an IRM can be acquired by mapping the ordered pairs of $(\mathrm{D}+\mathrm{R}, \mathrm{D}-\mathrm{R})$, which provides more valuable information for problem solving.

Step 6. Determine the influential weights of criteria

After the DEMATEL confirms the influential relationships between the dimensions and criteria, we use the causal diagram to measure the criteria weights that will be used in the decision making process (Dalalah et al., 2011; Baykasoğlu et al., 2013). The relative importance of the criteria is calculated with the following equation:

$$
w_{j}=\left[\left(D_{i}+R_{i}\right)^{2}+\left(D_{i}-R_{i}\right)^{2}\right]^{\frac{1}{2}}
$$

The weight of any criterion can be normalized as follows:

$$
\bar{W}_{j}=\frac{w_{j}}{\sum_{j=1}^{n} w_{j}}
$$

Where $\bar{W}_{j}$ represents the final criteria weights to be used in the decision making process.

\subsection{The FVIKOR technique}

VIKOR is one of the multi-criterion decision making techniques, which was developed by Opricovic (1998) and Opricovic \& Tzeng (2002) with Serbian name; VlseKriterijumska Optimizacija I Kompromisno Resenje, means multi-criterion optimization and compromise solution (Pal \& Gauri, 2010). The VIKOR was developed as a multi criteria decision making technique to solve a discrete decision problem with non-commensurable and conflicting criteria (Opricovic \& Tzeng, 2004; Sanayei et al., 2010; Opricovic \& Tzeng, 2007). Fuzzy VIKOR intends to find the decision-makers preferable compromise that suits human objective cognition (Wang, 2006). It is generally hard to find an alternative that meets all the criteria simultaneously, so a good compromise solution is preferred. This problem may become more complex when multiple decision-makers with different perception on the alternatives are involved. Thus, VIKOR is a useful technique for ranking and sorting a set of 
alternatives. There is uncertainty related to the research data. Then fuzzy MADM was used. Fuzzy logic suggested that decision makers can use linguistic variables. Fuzzy VIKOR was described By Wang and Chang (2005). The procedure of the FDEMATEL algorithm can be given as follows (Opricovic 2011; Opricovic \& Tzeng, 2007; Shemshadi et al., 2011; Wang, 2006; Huang et al., 2009):

Step 1. Form a group of decision-makers (denoted in $\mathrm{n}$ ), then determine the evaluation criteria (denoted in $\mathrm{k}$ ) and feasible alternatives (denoted in $\mathrm{m}$ ).

Step 2. Define linguistic variables and their corresponding triangular fuzzy numbers. Linguistic variables are used to evaluate the importance of the criteria and the ratings of alternatives with respect to various criteria. (As shown in Table 3).

\section{Table 3}

Linguistic variables for rating the alternatives (Sun, 2010)

\begin{tabular}{cc}
\hline Linguistic terms & Linguistic value \\
\hline Very poor & $(0,1,3)$ \\
Poor & $(1,3,5)$ \\
Moderate & $(3,5,7)$ \\
Good & $(5,7,9)$ \\
Very good & $(7,9,10)$ \\
\hline
\end{tabular}

Step 3. Construct a fuzzy decision matrix. Calculate fuzzy weighted average and construct the (normalized) fuzzy decision matrix, where $\tilde{X}_{i j}$ is the rating of alternative $\tilde{A}_{i}$ with respect to criterion $C_{j}$, and $\widetilde{W}_{j}$ is the important weight of the $j$ th criterion. This study, therefore, denotes linguistic variables $\widetilde{X}_{i j}$ and $\widetilde{W}_{j}$ as triangular fuzzy numbers.

Step 4. Determine the fuzzy best value (FBV) and fuzzy worst value (FWV):

$$
\begin{array}{llll}
\tilde{f}_{j}^{*}=\max _{i} \tilde{f}_{i j} & \mathrm{i}=1,2, \ldots, \mathrm{n} & \text { for } & j \in j^{b} \text { (profit) } \\
\tilde{\mathrm{f}}_{\mathrm{j}}^{\circ}=\min _{\mathrm{i}} \tilde{\mathrm{f}}_{\mathrm{ij}} & \mathrm{i}=1,2, \ldots, \mathrm{n} & \text { for } & j \in j^{b} \text { (profit) } \\
\tilde{f}_{j}^{*}=\min _{i} \tilde{f}_{i j} & \mathrm{i}=1,2, \ldots, \mathrm{n} & \text { for } & j \in j^{c} \text { (cost) } \\
\tilde{f}_{j}^{\circ}=\max _{i} \tilde{f}_{i j} & \mathrm{i}=1,2, \ldots, \mathrm{n} & \text { for } & j \epsilon j^{c} \text { (cost) }
\end{array}
$$

Step 5. Calculate the values:

$$
\begin{aligned}
& \tilde{S}_{i}=\sum_{j=1}^{J}\left(\widetilde{W}_{j} \otimes \tilde{d}_{i j}\right) \\
& \widetilde{\mathrm{R}}_{\mathrm{i}}=\max _{\mathrm{j}}\left(\widetilde{\mathrm{W}}_{\mathrm{j}} \otimes \tilde{\mathrm{d}}_{\mathrm{ij}}\right)
\end{aligned}
$$

In which:

$$
\begin{aligned}
& \tilde{\mathrm{d}}_{\mathrm{ij}}=\left(\tilde{f}_{j}^{*} \ominus \tilde{f}_{i j}\right) /\left(r_{j}^{*}-l_{j}^{\circ}\right) \text { (profit) } \\
& \tilde{\mathrm{d}}_{\mathrm{ij}}=\left(\tilde{f}_{i j} \ominus \tilde{f}_{j}^{*}\right) /\left(r_{j}^{\circ}-l_{j}^{*}\right)(\text { cost })
\end{aligned}
$$

where $\tilde{S}_{i}$ refers to the separation measure of $\tilde{A}_{i}$ from the fuzzy best value, similarly, $\tilde{R}_{i}$ is the separation measure of $\tilde{A}_{i}$ from the FWV, and $\widetilde{W}_{j}$ is the weight of each criterion. 
Step 6. Calculate the values of:

$$
\begin{aligned}
& \widetilde{\mathrm{S}}^{*}=\min _{\mathrm{i}} \widetilde{\mathrm{S}}_{\mathrm{i}} \\
& \tilde{\mathrm{S}}^{\circ}=\max _{\mathrm{i}} \mathrm{S}_{\mathrm{i}}^{\mathrm{r}} \\
& \widetilde{\mathrm{R}}^{*}=\min _{\mathrm{i}} \widetilde{\mathrm{R}}_{\mathrm{i}} \\
& \widetilde{\mathrm{R}}^{\circ}=\max _{i} \mathrm{R}_{\mathrm{i}}^{\mathrm{r}} \\
& \tilde{Q}_{i}=v \frac{\left(\tilde{S}_{j} \Theta \tilde{S}^{*}\right)}{S^{\circ} r-S^{* l}} \oplus(1-v) \frac{\left(\tilde{R}_{j} \Theta \tilde{R}^{*}\right)}{R^{\circ}-R^{* l}}
\end{aligned}
$$

The index $\min \tilde{S}_{i}$ is with a maximum majority rule, and $\min \tilde{R}_{i}$ is with a minimum individual regret of an opponent strategy. As well, $v$ is introduced as weight of the strategy of the maximum group utility, usually $v=0.5$, whereas $1-v$ is the weight of the individual regret.

Step 7. The next step is defuzzification of triangular fuzzy number $\tilde{S}_{i}, \tilde{R}_{i}$ and $Q_{i}$ to crisp number. Here the defuzzification method, the second weighted mean, is applied to convert a fuzzy number into crisp score, which is shown as next Equation:

$$
\mathrm{B}=\frac{l+2 m+u}{4}
$$

Step 8. Rank the alternatives, sorting by the values $\tilde{S}_{i}, \tilde{R}_{i}$ and $Q_{i}$ in ascending order.

Step 9. Propose as a compromise solution the alternative $A^{(1)}$ which is best ranked by the measure $Q_{i}$ (minimum) if the following two conditions are satisfied.

$\mathrm{C}_{1}$. Acceptable advantage:

$$
\mathrm{Q}\left(A^{(2)}\right)-\mathrm{Q}\left(A^{(1)}\right) \geq \mathrm{DQ}
$$

where $A^{(2)}$ is the alternative with second position in the ranking list by:

$$
\mathrm{Q}: \mathrm{DQ}=\frac{1}{m-1}
$$

$C_{2}$. Acceptable stability in decision-making:

The alternative $A^{(1)}$ must also be best ranked by $\tilde{S}_{i}$ or/and $\tilde{R}_{i}$. This compromise solution is stable within a decision making process, which could be the strategy of maximum group utility (when $v>0.5$ is needed), or "by consensus" $v \approx 0.5$, or with vector $(v \leq 0.5)$. Here, $v$ is the weight of decision making strategy of maximum group utility. If one of the conditions is not satisfied, a set of compromise solutions is proposed, which consists of:

- Alternatives $A^{(1)}$ and $A^{(2)}$ if only the condition $C_{2}$ is not satisfied, or

- Alternatives $A^{(1)}, A^{(2)}, \ldots, A^{(M)}$ if the condition $\mathrm{C}_{1}$ is not satisfied; $A^{(M)}$ is determined by the relation:

$$
\mathrm{Q}\left(A^{(M)}\right)-\mathrm{Q}\left(A^{(1)}\right)<\mathrm{DQ}
$$

For maximum $\mathrm{M}$ the positions of these alternatives are in closeness.

\section{Case study: selection of project manager}

In this section, an empirical study conducted in an Iranian company (zarrin balan shomal) which is the best producer of Livestock and poultry food in mazandran, is presented to illustrate the application of the proposed hybrid decision making model. In this company Stakeholders decided to build a large office building in Babol city. They needed a good manager for this project. Therefore 6 experts and 
managers were invited to survey four alternatives (Available project managers) using the research framework shown in Fig. 1. Through the literature investigation, experts' opinions and International Project Management Association competence baseline (ICB-IPMA, 2006), the committee finally adopted 5 criteria. Table 4 shows this criteria.

Table 4

Criteria for project manager selection

\begin{tabular}{|c|c|}
\hline Criteria & definition \\
\hline Site management capacity $(\mathrm{C} 1)$ & $\begin{array}{l}\text { That include this skills: Project management, Cost management, Quality } \\
\text { management, Purchase and machinery and equipment management }\end{array}$ \\
\hline Technical level(C2) & $\begin{array}{l}\text { That include this skills: Level of expertise linked to a specific project, General } \\
\text { technical level in construction }\end{array}$ \\
\hline Level of leadership(C3) & $\begin{array}{l}\text { That include this skills: Communication skills, Human resource management } \\
\text { capacity, Risk management capability, Ability to create efficient working } \\
\text { environment }\end{array}$ \\
\hline Personal qualities(C4) & $\begin{array}{l}\text { That include this skills: Achievement-oriented and good at action, Ability to } \\
\text { influence, Cognitive ability }\end{array}$ \\
\hline Contextual competences(C5) & $\begin{array}{l}\text { That include this skills: Project orientation, Program orientation, Portfolio } \\
\text { orientation, Project program and portfolio implementation, Permanent } \\
\text { organization, Health, security, safety and environment }\end{array}$ \\
\hline
\end{tabular}

After that subject to the fuzzy linguistic scale for FDEMATEL Technique showed in Table 2, every Experts is asked to make pair wise relationships between each pair of 5 criteria. Then, we will have 6 Assessment Data Fuzzy Matrix in hand. Using (1) to average all these assessments matrices, we will have initial-direct fuzzy matrix $\tilde{z}$. The results are shown in Table 5 .

\section{Table 5}

Initial-direct fuzzy matrix

\begin{tabular}{cccccc}
\hline & $\mathrm{C}_{1}$ & $\mathrm{C}_{2}$ & $\mathrm{C}_{3}$ & $\mathrm{C}_{4}$ & $\mathrm{C}_{5}$ \\
\hline $\mathrm{C}_{1}$ & $(0.00,0.00,0.00)$ & $(0.00,0.25,0.5)$ & $(0.00,0.00,0.25)$ & $(0.00,0.25,0.5)$ & $(0.00,0.25,0.5)$ \\
$\mathrm{C}_{2}$ & $(0.00,0.25,0.5)$ & $(0.00,0.00,0.00)$ & $(0.00,0.00,0.25)$ & $(0.00,0.04,0.29)$ & $(0.00,0.21,0.46)$ \\
$\mathrm{C}_{3}$ & $(0.67,0.92,1.00)$ & $(0.75,1.00,1.00)$ & $(0.00,0.00,0.00)$ & $(0.21,0.46,0.71)$ & $(0.46,0.71,0.96)$ \\
$\mathrm{C}_{4}$ & $(0.5,0.75,1.00)$ & $(0.54,0.79,1.00)$ & $(0.00,0.08,0.33)$ & $(0.00,0.00,0.00)$ & $(0.21,0.46,0.71)$ \\
$\mathrm{C}_{5}$ & $(0.29,0.54,0.79)$ & $(0.5,0.75,1.00)$ & $(0.00,0.00,0.25)$ & $(0.00,0.21,0.46)$ & $(0.00,0.00,0.00)$ \\
\hline
\end{tabular}

Then, using Eq. (2), the normalized direct-relation fuzzy matrix $\widetilde{H}$ will be produced. The partial results of our case study are depicted in Table 6 .

Table 6

Normalized direct-relation fuzzy matrix

\begin{tabular}{cccccc}
\hline & $\mathrm{C}_{1}$ & $\mathrm{C}_{2}$ & $\mathrm{C}_{3}$ & $\mathrm{C}_{4}$ & $\mathrm{C}_{5}$ \\
\hline $\mathrm{C}_{1}$ & $(0.00,0.00,0.00)$ & $(0.07,0.13,0.20)$ & $(0.00,0.00,0.07)$ & $(0.00,0.07,0.13)$ & $(0.00,0.07,0.13)$ \\
$\mathrm{C}_{2}$ & $(0.00,0.07,0.13)$ & $(0.00,0.00,0.00)$ & $(0.00,0.00,0.07)$ & $(0.00,0.01,0.08)$ & $(0.00,0.06,0.12)$ \\
$\mathrm{C}_{3}$ & $(0.18,0.24,0.27)$ & $(0.20,0.27,0.27)$ & $(0.00,0.00,0.00)$ & $(0.06,0.12,0.19)$ & $(0.12,0.19,0.25)$ \\
$\mathrm{C}_{4}$ & $(0.18,0.20,0.27)$ & $(0.14,0.21,0.27)$ & $(0.00,0.02,0.09)$ & $(0.00,0.00,0.00)$ & $(0.06,0.12,0.19)$ \\
$\mathrm{C}_{5}$ & $(0.08,0.14,0.21)$ & $(0.13,0.20,0.27)$ & $(0.00,0.00,0.07)$ & $(0.00,0.06,0.12)$ & $(0.00,0.00,0.00)$ \\
\hline
\end{tabular}

Following Eq. (4), we will acquire the total-relation fuzzy matrix. Our matrix partially depicted on Table 7. Then total-relation fuzzy matrix defuzified through defuzification method (10). The results showed on Table 8 .

To access the casual relationships between criteria, we will calculate $\left(\widetilde{D}_{i}+\widetilde{R}_{i}\right)^{\text {def }}$ and $\left(\widetilde{D}_{i}-\widetilde{R}_{i}\right)^{\text {def }}$ in which $\widetilde{D}_{i}$ and $\tilde{R}_{i}$ are the sum of row and the sum of columns of our total-relation fuzzy matrix respectively. Our partial results are shown in Table 9. 
Table 7

Total-relation fuzzy matrix

\begin{tabular}{cccccc}
\hline & $\mathrm{C}_{1}$ & $\mathrm{C}_{2}$ & $\mathrm{C}_{3}$ & $\mathrm{C}_{4}$ & $\mathrm{C}_{5}$ \\
\hline $\mathrm{C}_{1}$ & $(0.00,0.04,0.24)$ & $(0.07,0.17,0.45)$ & $(0.00,0.00,0.16)$ & $(0.00,0.08,0.26)$ & $(0.00,0.09,0.31)$ \\
$\mathrm{C}_{2}$ & $(0.00,0.09,0.3)$ & $(0.00,0.03,0.22)$ & $(0.00,0.00,0.14)$ & $(0.00,0.02,0.2)$ & $(0.00,0.07,0.26)$ \\
$\mathrm{C}_{3}$ & $(-0.11,0.34,0.64)$ & $(-0.12,0.4,0.7)$ & $(0.00,0.00,0.17)$ & $(0.06,0.16,0.43)$ & $(-0.01,0.26,0.54)$ \\
$\mathrm{C}_{4}$ & $(0.24,0.25,0.56)$ & $(0.28,0.29,0.62)$ & $(0.00,0.02,0.22)$ & $(0.00,0.03,0.22)$ & $(0.11,0.16,0.43)$ \\
$\mathrm{C}_{5}$ & $(-2.41,0.18,0.45)$ & $(-2.76,0.25,0.55)$ & $(0.00,0.00,0.18)$ & $(0.00,0.08,0.28)$ & $(-1.11,0.04,0.22)$ \\
\hline
\end{tabular}

Table 8

Defuzified total-relation matrix

\begin{tabular}{cccccc}
\hline & $\mathrm{C}_{1}$ & $\mathrm{C}_{2}$ & $\mathrm{C}_{3}$ & $\mathrm{C}_{4}$ & $\mathrm{C}_{5}$ \\
\hline $\mathrm{C}_{1}$ & 0.08 & 0.22 & 0.04 & 0.11 & 0.12 \\
$\mathrm{C}_{2}$ & 0.12 & 0.07 & 0.04 & 0.06 & 0.10 \\
$\mathrm{C}_{3}$ & 0.30 & 0.35 & 0.04 & 0.20 & 0.26 \\
$\mathrm{C}_{4}$ & 0.33 & 0.37 & 0.07 & 0.07 & 0.22 \\
$\mathrm{C}_{5}$ & -0.40 & -0.43 & 0.05 & 0.11 & -0.20 \\
\hline
\end{tabular}

\section{Table 9}

Casual relationships between criteria

\begin{tabular}{ccc}
\hline Criteria & $\mathrm{D}+\mathrm{R}$ & $\mathrm{D}-\mathrm{R}$ \\
\hline $\mathrm{C}_{1}$ & 0.99 & 0.14 \\
$\mathrm{C}_{2}$ & 0.96 & -0.19 \\
$\mathrm{C}_{3}$ & 1.38 & 0.93 \\
$\mathrm{C}_{4}$ & 1.59 & 0.50 \\
$\mathrm{C}_{5}$ & -0.38 & -1.37 \\
\hline
\end{tabular}

Then, we have two sets of numbers: $\left(\widetilde{D}_{i}+\widetilde{R}_{i}\right)^{\text {def }}$ which shows the importance of all criteria by aggregation of all managers' preferences and $\left(\widetilde{D}_{i}-\widetilde{R}_{i}\right)^{\text {def }}$ which assign criteria into cause and effect groups. As the shown in Table 9, the criteria are divided into two groups. The first is cause group which implies C1, C3, C4 and effect group which implies the rest of the criteria. Then, the IRM of the given application can be constructed by using the vectors $\mathrm{d}$ and $\mathrm{r}$ in the total-influence matrix $\mathrm{T}$, as expressed in Fig. 2. Finally The relative importance of the criteria calculated by Eq. (12). The results are depicted in Table 10.

Table 10

Relative weights of criteria

\begin{tabular}{lccccc}
\hline Criteria & $\mathrm{C}_{1}$ & $\mathrm{C}_{2}$ & $\mathrm{C}_{3}$ & $\mathrm{C}_{4}$ & $\mathrm{C}_{5}$ \\
\hline $\bar{W}_{j}$ & 0.14843 & 0.144943 & 0.247314 & 0.247849 & 0.211463 \\
\hline
\end{tabular}

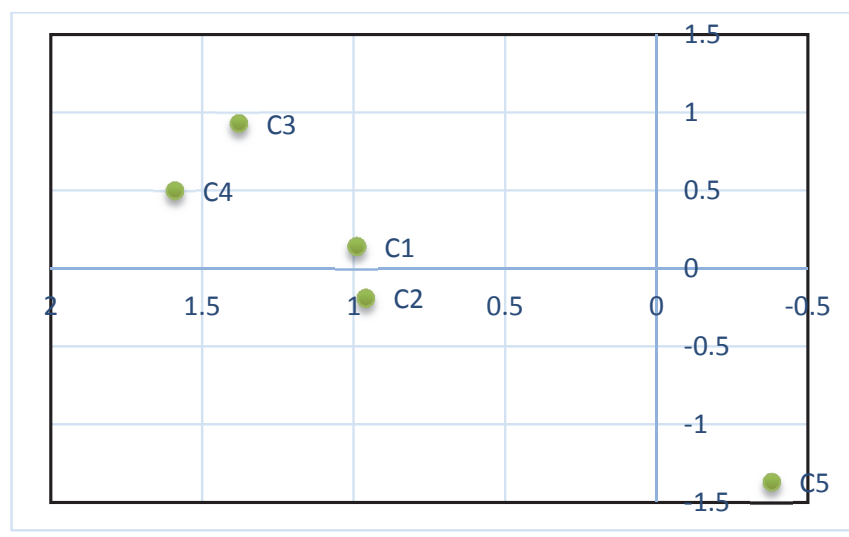

Fig. 2. Influential relation map among the criteria 
The weights of the alternatives are calculated by FDEMATEL up to now, and then these values can be used in FVIKOR. So, the FVIKOR methodology must be started at the second step. According to the Table 3, linguistic terms converted and aggregated to the triangular fuzzy number and decision matrix was constructed as Table 11. Then, weighted normalized decision matrix can be prepared. This matrix can be seen from Table 12. By following FVIKOR procedure steps and calculations, the ranking of project managers are obtained. The results and final ranking are shown in Table 13.

\section{Table 11}

Aggregated triangular fuzzy decision matrix

\begin{tabular}{cccccc}
\hline \multicolumn{7}{c}{$\mathrm{C} 1$} & $\mathrm{C} 2$ & $\mathrm{C} 3$ & $\mathrm{C} 4$ & $\mathrm{C} 5$ \\
\hline $\mathrm{A} 1$ & $(4,6,8)$ & $(1.833,3.333,5.333)$ & $(5,7,9)$ & $(5.333,7.333,9.167)$ & $(4.667,6.667,8.333)$ \\
$\mathrm{A} 2$ & $(5,7,9)$ & $(2.167,4,6)$ & $(7,9,10)$ & $(7,9,10)$ & $(5.667,7.667,9.333)$ \\
A3 & $(1.167,2.667,4.667)$ & $(3.833,5.667,7.5)$ & $(3.667,5.667,7.667)$ & $(3.333,5.333,7.333)$ & $(4.667,6.667,8.667)$ \\
A4 & $(1,2.667,4.667)$ & $(4.667,6.667,8.167)$ & $(0.667,2.333,4.333)$ & $(0.5,2,4)$ & $(2.833,4.667,6.667)$ \\
A5 & $(2.333,4.333,6.333)$ & $(2.667,4.667,6.667)$ & $(2.333,4.333,6.333)$ & $(2.333,4.333,6.333)$ & $(1.833,3.667,5.667)$ \\
\hline Weight & $(0.148,0.148,0.148)$ & $(0.144943,0.144943,0.144943)$ & $(0.247,0.247,0.247)$ & $(0.247849,0.247849,0.247849)$ & $(0.211,0.211,0.211)$ \\
\hline
\end{tabular}

Table 12

Weighted normalized decision matrix

\begin{tabular}{cccccc}
\hline & C1 & C2 & C3 & C4 & C5 \\
\hline A1 & $(-0.375,0.125,0.625)$ & $(-0.105,0.526,1)$ & $(-0.214,0.214,0.536)$ & $(-0.228,0.175,0.491)$ & $(-0.356,0.133,0.622)$ \\
A2 & $(-0.5,0,0.5)$ & $(-0.211,0.421,0.947)$ & $(-0.321,0,0.321)$ & $(-0.316,0,0.316)$ & $(-0.489,0,0.489)$ \\
A3 & $(0.042,0.542,0.979)$ & $(-0.447,0.158,0.684)$ & $(-0.071,0.357,0.679)$ & $(-0.035,0.386,0.702)$ & $(-0.4,0.133,0.622)$ \\
A4 & $(0.042,0.542,1)$ & $(-0.553,0,0.553)$ & $(0.286,0.714,1)$ & $(0.316,0.737,1)$ & $(-0.133,0.4,0.867)$ \\
A5 & $(-0.167,0.333,0.833)$ & $(-0.316,0.316,0.868)$ & $(0.071,0.5,0.821)$ & $(0.07,0.491,0.807)$ & $(0,0.533,1)$ \\
\hline
\end{tabular}

Table 13

Index Qi and final rank

\begin{tabular}{cccc}
\hline & Q & Qg & Final Rank \\
\hline A1 & $(-0.606,0.098,0.722)$ & 2 & 0.078 \\
A2 & $(-0.648,0,0.648)$ & 0 & 0.113 \\
A3 & $(-0.608,0.136,0.788)$ & 3 & 0.35 \\
A4 & $(-0.368,0.385,1)$ & 5 & 0.217 \\
A5 & $(-0.521,0.244,0.901)$ & 4 \\
\hline
\end{tabular}

According to the above empirical study, the proposed hybrid FMCDM model provides some important findings. First, in accordance with the results of FDEMATEL (see Table 10), Personal qualities (C4) is the most important criterion with influence weight of 0.247849 , and Technical level (C2) is the least important one with influence weight of 0.144943 . Second, the FDEMATEL method can also be utilized to understand the interrelationship among dimensions and criteria (Fig. 2). The IRM shows that Level of leadership (C3), Personal qualities (C4) and Site management capacity (C1) criteria have more influence over the other two criteria. This finding means that they are the most important relative to the other criteria. Third, from the results obtained by fuzzy VIKOR (see Table 13), the ranking order of the project managers alternatives is $\mathrm{A} 2>\mathrm{A} 1>\mathrm{A} 3>\mathrm{A} 5>\mathrm{A} 4$, suggesting (A2) as the most suitable project manager for this project.

\section{Conclusions}

The selection of a project manager from a set of potential candidates is an important, difficult, and timeconsuming task for managers of any company. This problem worsens with an increase in the number of alternatives. There is also a risk of human error in judgment and decision making. There is therefore a need for computational models that can increase the accuracy of decisions and reduce the time required. An appropriate and simple prioritization method for determining the best project manager would be helpful to firms. A two-step fuzzy-DEMATEL and Fuzzy-VIKOR methodology is structured 
here that FVIKOR uses FDEMATEL result weights as input weights. Then a real case study in zarrin balan shomal firm presented to show applicability and performance of the methodology. First, with the opinions of the senior managers based on project management competency model (ICB-IPMA), all the criteria and required for project manager selection are gathered. Then The FDEMATEL method is used to prioritize the importance of various criteria and FVIKOR used to rank the alternatives in a preferred order to select the best project managers from a number of alternatives. The results of this study showed that the most important criteria for project manager selection was Personal qualities (C4), and the most suitable project manager was alternative (2). As a future step to this paper could be the comparison of the proposed approach to other FMCDM methods, like FTOPSIS, FAHP, FANP or even more to the outranking methods, such as FELECTRE and FPROMETHEE.

\section{References}

Afshari, A. R., \& Yusuff, R. M. (2012). Developing a Structural Method for Eliciting Criteria in Project Managaer Selection. In Proceedings of the 2012 International Conference on In-dustrial Engineering and Operations Management, Istanbul (pp. 150-158).

Afshari, A. R., Yusuff, R., \& Derayatifar, A. R. (2012, May). Project manager selection by using Fuzzy Simple Additive Weighting method. In Innovation Management and Technology Research (ICIMTR), 2012 International Conference on (pp. 412-416). IEEE.

Al-Harbi, K. M. A. S. (2001). Application of the AHP in project management. International journal of project management, 19(1), 19-27.

Archibald, S. C., \& Archibald, R. D. (2013). Leading \& Managing Innovation: What Every Executive Team Must Know about Project, Program \& Portfolio Management. PROJECT MANAGER (IL).

Baykasoglu, A., Dereli, T., \& Das, S. (2007). Project team selection using fuzzy optimization approach. Cybernetics and Systems: An International Journal, 38(2), 155-185.

Baykasoğlu, A., KaplanoğLu, V., DurmuşOğLu, Z. D., \& ŞAhin, C. (2013). Integrating fuzzy DEMATEL and fuzzy hierarchical TOPSIS methods for truck selection. Expert Systems with Applications, 40(3), 899-907.

Bayraktaroglu, A. E., Calisir, F., \& Gumussoy, C. A. (2009, December). Usability and functionality: A comparison of project managers' and potential users' evaluations. In Industrial Engineering and Engineering Management, 2009. IEEM 2009. IEEE International Conference on (pp. 2019-2023). IEEE.

Cebi, S. (2013). Determining importance degrees of website design parameters based on interactions and types of websites. Decision Support Systems, 54(2), 1030-1043.

Chen, C. T., \& Hung, W. Z. (2012, November). Choosing project leader based on interval linguistic TOPSIS and social network technology. In Fuzzy Theory and it's Applications (iFUZZY), 2012 International Conference on (pp. 310-315). IEEE.

Chen, C. T., Pai, P. F., \& Hung, W. Z. (2013). A new decision-making process for selecting project leader based on social network and knowledge map. International Journal of Fuzzy Systems, 15(1), 36-46.

Chen, L. S., \& Cheng, C. H. (2005). Selecting IS personnel use fuzzy GDSS based on metric distance method. European Journal of Operational Research, 160(3), 803-820.

Chen, S. H., \& Lee, H. T. (2007). Performance evaluation model for project managers using managerial practices. International Journal of Project Management, 25(6), 543-551.

Dağdeviren, M. (2010). A hybrid multi-criteria decision-making model for personnel selection in manufacturing systems. Journal of Intelligent manufacturing, 21(4), 451-460.

Dainty, A. R., Cheng, M. I., \& Moore, D. R. (2005). Competency-based model for predicting construction project managers' performance. Journal of Management in Engineering.

Dalalah, D., Hayajneh, M., \& Batieha, F. (2011). A fuzzy multi-criteria decision making model for supplier selection. Expert systems with applications, 38(7), 8384-8391.

Dodangeh, J., Sorooshian, S., \& Afshari, A. R. (2014). Linguistic extension for group multicriteria project manager selection. Journal of Applied Mathematics, 2014. 
Dursun, M., \& Karsak, E. E. (2010). A fuzzy MCDM approach for personnel selection. Expert Systems with Applications, 37(6), 4324-4330.

El-Sabaa, S. (2001). The skills and career path of an effective project manager. International journal of project management, 19(1), 1-7.

Goodwin, R. S. (1993). Skills required of effective project managers. Journal of Management in Engineering, 9(3), 217-226.

Hadad, Y., Keren, B., \& Laslo, Z. (2013). A decision-making support system module for project manager selection according to past performance. International Journal of Project Management, 31(4), 532-541.

Huang, Y., Yan, Y., \& Qiu, Z. (2009, April). Research on supply-chain-based logistics service capability by combination weighting method and fuzzy VIKOR algorithm. In Measuring Technology and Mechatronics Automation, 2009. ICMTMA'09. International Conference on (Vol. 2, pp. 574-577). IEEE.

Hui, Z., Xue-Qing, W., Gang, Y., \& Li-Fu, Z. (2008, October). Study on engineering project manager selection. In Wireless Communications, Networking and Mobile Computing, 2008. WiCOM'08. 4th International Conference on (pp. 1-4). IEEE.

International Project Management Association. (2006). ICB-IPMA competence baseline version 3.0. International Project Management Association, Nijkerk.

Jazebi, F., \& Rashidi, A. (2013). An automated procedure for selecting project managers in construction firms. Journal of Civil Engineering and Management, 19(1), 97-106.

Kelemenis, A., Ergazakis, K., \& Askounis, D. (2011). Support managers' selection using an extension of fuzzy TOPSIS. Expert Systems with Applications, 38(3), 2774-2782.

Lin, C. L., \& Wu, W. W. (2004). A fuzzy extension of the DEMATEL method for group decision making.

Liqin, Z., Yuexian, G., \& Wenming, C. (2009, November). The application of fuzzy comprehensive evaluation methods in the selection of a project manager. In Computer Sciences and Convergence Information Technology, 2009. ICCIT'09. Fourth International Conference on (pp. 1387-1391). IEEE.

Liu, H. C., You, J. X., Zhen, L., \& Fan, X. J. (2014). A novel hybrid multiple criteria decision making model for material selection with target-based criteria. Materials \& Design, 60, 380-390.

Manaan, O. A., Ahadzie, D. K., Panford, J. K., \& Proverbs, D. G. (2014). Competency-based evaluation of project managers' performance in mass house building projects in Ghana-the fuzzy set theory approach. Journal of Science and Technology (Ghana), 34(1), 46-62.

Müller, R., \& Turner, J. R. (2007). Matching the project manager's leadership style to project type. International journal of project management, 25(1), 21-32.

Müller, R., \& Turner, R. (2010). Leadership competency profiles of successful project managers. International Journal of Project Management, 28(5), 437-448.

Opricovic, S. (1998). Multicriteria optimization of civil engineering systems. Belgrade, Serbia.

Opricovic, S. (2011). Fuzzy VIKOR with an application to water resources planning. Expert Systems with Applications, 38(10), 12983-12990.

Opricovic, S., \& Tzeng, G. H. (2002). Multicriteria planning of post-earthquake sustainable reconstruction. Computer-Aided Civil and Infrastructure Engineering, 17(3), 211-220.

Opricovic, S., \& Tzeng, G. H. (2004). Compromise solution by MCDM methods: A comparative analysis of VIKOR and TOPSIS. European Journal of Operational Research, 156(2), 445-455.

Opricovic, S., \& Tzeng, G. H. (2007). Extended VIKOR method in comparison with outranking methods. European Journal of Operational Research, 178(2), 514-529.

Pal, S., \& Gauri, S. K. (2010). Multi-Response Optimization Using Multiple Regression-Based Weighted Signal-to-Noise Ratio (MRWSN). Quality Engineering, 22(4), 336-350.

Petrovic-Lazarevic, S. (2001). Personnel selection fuzzy model. International Transactions in Operational Research, 8(1), 89-105.

Pinto, J. K., \& Slevin, D. P. (1987). Critical factors in successful project implementation. Engineering Management, IEEE Transactions on, (1), 22-27. 
Rashidi, A., Jazebi, F., \& Brilakis, I. (2010). Neurofuzzy genetic system for selection of construction project managers. Journal of Construction Engineering and Management, 137(1), 17-29.

Robertson, I. T., \& Smith, M. (2001). Personnel selection. Journal of occupational and Organizational psychology, 74(4), 441-472.

Sadeghi, H., Mousakhani, M., Yazdani, M., \& Delavari, M. (2014). Evaluating project managers by an interval decision-making method based on a new project manager competency model. Arabian Journal for Science and Engineering, 39(2), 1417-1430.

Sanayei, A., Mousavi, S. F., \& Yazdankhah, A. (2010). Group decision making process for supplier selection with VIKOR under fuzzy environment. Expert Systems with Applications, 37(1), 24-30.

Shemshadi, A., Shirazi, H., Toreihi, M., \& Tarokh, M. J. (2011). A fuzzy VIKOR method for supplier selection based on entropy measure for objective weighting. Expert Systems with Applications, $38(10), 12160-12167$.

Shih, H. S., Shyur, H. J., \& Lee, E. S. (2007). An extension of TOPSIS for group decision making. Mathematical and Computer Modelling, 45(7), 801-813.

Sun, C. C. (2010). A performance evaluation model by integrating fuzzy AHP and fuzzy TOPSIS methods. Expert Systems with Applications, 37(12), 7745-7754.

Torfi, F., \& Rashidi, A. (2011). Selection of project managers in construction Firms using analytic hierarchy process (AHP) and fuzzy Topsis: a case study. Journal of Construction in Developing Countries, 16(1), 69-89.

Vainiūnas, P., Zavadskas, E. K., Turskis, Z., \& Tamošaitienè, J. (2010). Design Projects' Managers Ranking Based on Their Multiple Experience And Technical Skills.

Varajão, J., \& Cruz-Cunha, M. M. (2013). Using AHP and the IPMA Competence Baseline in the project managers selection process. International Journal of Production Research, 51(11), 33423354.

Wang, T. C., Liang, J. L., \& Ho, C. Y. (2006, October). Multi-criteria decision analysis by using fuzzy VIKOR. In Service Systems and Service Management, 2006 International Conference on (Vol. 2, pp. 901-906). IEEE.

Wang,T.-C.,\&Chang,T.-H. (2005). Fuzzy VIKORas an aid formultiple criteria decision making. Taiwan: Institute of Information Management I-Shou University.

Xing, B., \& Zhang, A. (2006, October). Application of fuzzy analytical hierarchy process in selecting a project manager. In Management Science and Engineering, 2006. ICMSE'06. 2006 International Conference on (pp. 1417-1421). IEEE.

Zavadskas, E. K., Turskis, Z., Tamošaitiene, J., \& Marina, V. (2008). Multicriteria selection of project managers by applying grey criteria. Technological and Economic Development of Economy, 14(4), 462-477.

Zavadskas, E. K., Vainiūnas, P., Turskis, Z., \& Tamošaitienè, J. (2012). Multiple criteria decision support system for assessment of projects managers in construction. International Journal of Information Technology \& Decision Making, 11(02), 501-520.

Zhang, S. F., \& Liu, S. Y. (2011). A GRA-based intuitionistic fuzzy multi-criteria group decision making method for personnel selection. Expert Systems with Applications, 38(9), 11401-11405. 